\title{
New Show Paradigm of Wayang Klithik Wonosoco
}

\author{
I Nyoman Murtana ${ }^{1}$ \\ Puppetry Department, Institut Seni Indonesia Surakarta
}

jurnal tari, teater, dan wayang

volume 1 number 2 ,

November 2018

page $84-95$

\begin{abstract}
Wayang Klithik Wonosoco is classified as rare because it is only performed once a year as a means of bersih desa ritual. However, the show still comes with a new paradigm. The results of the study show that the wayang Klithik Wonosoco Village has undergone a paradigm shift since puppeteer and several musicians studied at the Surakarta Kasunanan Palace. This research applied basic research method by applying the theory of change to enrich the basic knowledge. The basic understanding of the values of the cultural practices of wayang shows in the Surakarta Kasunanan Palace is converted to Wonosoco Village after going through an adaptation process. This article is expected to be an inspiration for the development of science and practice in the field of puppet art. The paradigm of Wayang Klithik Wonosoco has changed; as a result, it becomes new. The changes involve the concepts, methods, forms and structures of the staging which consists of jejer, babak unjal, paseban jawi, perang gagal, goro-goro, pertapan, perang brubuh, and tancep kayon. Likewise sulukan (puppeteer singing) is enriched with several cengkok sulukan of shadow puppet and pocapan (monologue) as signs of changing scenes in each pathet. The adaptation process has change the form and structure of Wayang Klithik Wonosoco show; it becomes new.
\end{abstract}

Keywords: Wayang Klithik; Wonosoco

\begin{abstract}
Abstrak
Seni Pertunjukan Wayang Klithik Wonosoco tergolong langka karena dipergelarkan hanya satu tahun sekali sebagai sarana ritual bersih desa, Namun demikian pertunjukan tersebut tetap hadir dengan paradigma baru. Hasil kajian menunjukan pertunjukan wayang Klithik Desa Wonosoco telah mengalami perubahan paradigma sejak dalang dan beberapa musisi belajar di Keraton Kasunanan Surakarta. Penelitian ini menerapkan metode penelitian dasar (basic research) dengan mengaplikasikan teori perubahan untuk memperkaya khasanah pengetahuan dasar atau murni. Pengertian dasar tentang nilai-nilai praktik budaya pertunjukan wayang di Keraton Kasunanan Surakarta dialih fungsi ke Desa Wonosoco setelah melalui proses adaptasi. Artikel ini diharapkan menjadi inspirasi pengembangan ilmu dan praktik di bidang seni pewayangan. Paradigma pertunjukan wayang Klithik Wonosoco sudah berubah, sehingga menjadi baru. Perubahaannya menyangkut konsep, metode, bentuk dan struktur pementasan yang terdiri atas jejer, babak unjal, paseban jawi, perang gagal, goro-goro, pertapan, perang brubuh, dan tancep kayon. Karawitan pakeliran yang semula hanya galak ganjur gaya Metaraman, kini tampil lebih variatif, karena sudah diperkaya dengan gending playon, gending dolanan, srepegan, dan sampak sala. Demikian juga sulukan (nyanyian dalang) diperkaya dengan beberapa cengkok sulukan wayang kulit dan pocapan (monolog) sebagai tanda
\end{abstract}

$\overline{1}$ Correspondence: Prodi Pedalangan, Institut Seni Indonesia Surakarta. Jln. Ki Hajar Dewantara no.19 Surakarta 57126. E-mail: nyomanmurtana@gmail.com, HP.: +6281329088782. 
pergantian adegan dalam setiap pathet. Proses adaptasi itu menjadikan bentuk dan struktur pertunjukan Wayang Klithik Wonosoco berubah dan baru.

Kata kunci: Wayang Klithik; Wonosoco

\section{Introduction}

Wayang Klithik Wonosoco show is one of the folk arts which until now is still maintained by the community to accompany each of the ceremonies of the bersih sendang ritual (spring). The show is always held every year since 1969. Starting in 2010, an elderly puppeteer, Ki Sumarlan, was replaced by Ki Sutikno. As a folk art, Wayang Klithik must follow the people's mindset in responding to changes in people's wish. Wayang Klithik Show faced enrichment as a bersih desa ritual and an appreciation event that entertains local villagers. The Wayang Klithik Wonosoco attracts many spectators, is well known in the local community, and has been a participant in several art shows at the sub-district level and at the regional level which took place in Alon-alon Kudus Regency. Another stage was held in front of members of the Kudus DPRD, and a national-level performance at the Taman Mini Indonesia Indah (Interview with Sutikno, 3-6-2012)

Due to the influence of globalization, Wayang Klithik show faced several changes towards a new paradigm. The new paradigm is a system of basic assumptions, a worldview that functions to guide human actions (Kutha Ratna, 2010: 39). The old paradigm of Wayang Klithik show was exhibited by Ki Sumarlan with garap Metaraman, accompaniment of karawitan Pakeliran (puppet gamelan music), and sulukan (dalang singing) only one type, namely Galak Ganjur Metaraman. The show atmosphere is monotonous and very simple (Subandi, 2010: 48). The young puppeteer, Ki Sutikno, was not satisfied with the situation, because it was considered to not accommodate creativity.

In $2010 \mathrm{Ki}$ Sutikno and a number of fellow villagers learned things about the practice of obstruction in the Surakarta Kasunanan
Palace. They studied the entire composition of the purwo shadow puppet show consisting of jejer, babak unjal, paseban jawi, perang gagal, goro-goro, pertapan, perang brubuh, and tancep kayon.

Since then there have been changes in the mindset of supporters of Wayang Klithik show that has an influence on the artistic paradigm. The paradigm also affects the mindset and attitudes of the people who are responsive to change. There are three things in response to changes that occur, (1) Changes in the composition of the population; (2) Widespread communication; (3) New community needs arise. The Wayang Klithik show has changed with the support of two large institutions, namely the Surakarta Palace and the Kudus Level I Regional Government through the Kudus Regency Tourism Service.

Wonosoco village, located in a rural area, was declared a tourist village by the Kudus Regency Tourism Service. The launching of tourist villages is a new paradigm of creative economy that has been buzzed by the Indonesian government, so that people's lives become more prosperous. Puppet shows can be used as objects of creative economic studies. In this regard, in September 2011,

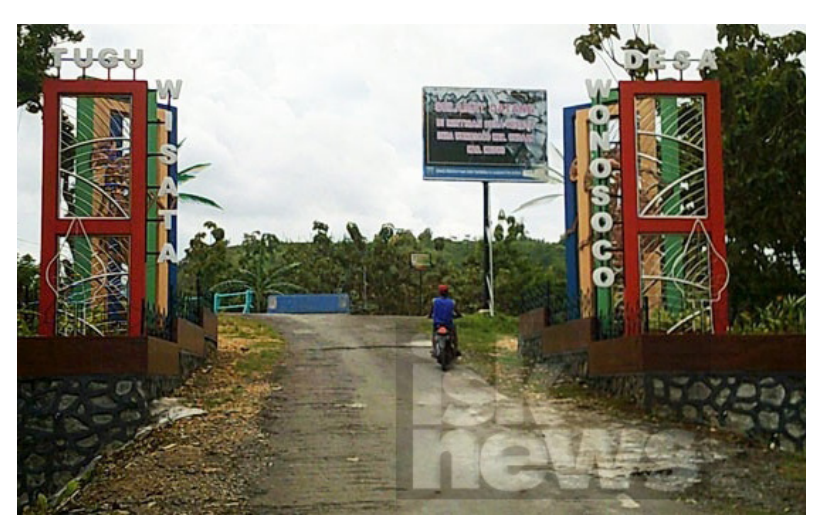

Figure 1. Wonosoco Village, Undaan Sub-district, Kudus Regency is one of four tourism pilot villages that received tourism monument assistance, from the Office of Culture and Tourism (Disbudpar) of Kudus Regency. 
Wonosoco Village was designated as a tourist village with Wayang Klithik show as one of the tourist attractions.

In this article the author uses basic research methods to realize the attention and curiosity of certain sciences that grow naturally (Nasir, 1983: 29). This nature expresses pure or basic knowledge. The nature of the puppet performance in the Surakarta Kasunanan Palace contained basic insights about the values of the practice of puppet culture. The form and structure of puppet shows are studied and have been converted into Wonosoco Village by Sutikno and friends through the process of adaptation and / or transfer into the form of Wayang Klithik show. The adaptation of the form and structure of the purwo shadow puppet show into the Wayang Klithik show caused a paradigm shift. Every change in culture takes place, undoubtedly causing a change in structure that needs to be recorded and analyzed by the text, context, and its benefits to the community. The author hopes that this article can be further developed by other researchers and / or other practitioners in the field of art, both for the development of art science that is both theoretical and practical.

The theory used in compiling this article is the theory of changing the paradigm of tradition. The theory is used to analyze changes in tradition and its continuity that are closely related to space and time. With regard to changing traditions, Sztompka (Sztompka, 2007: 68) said:

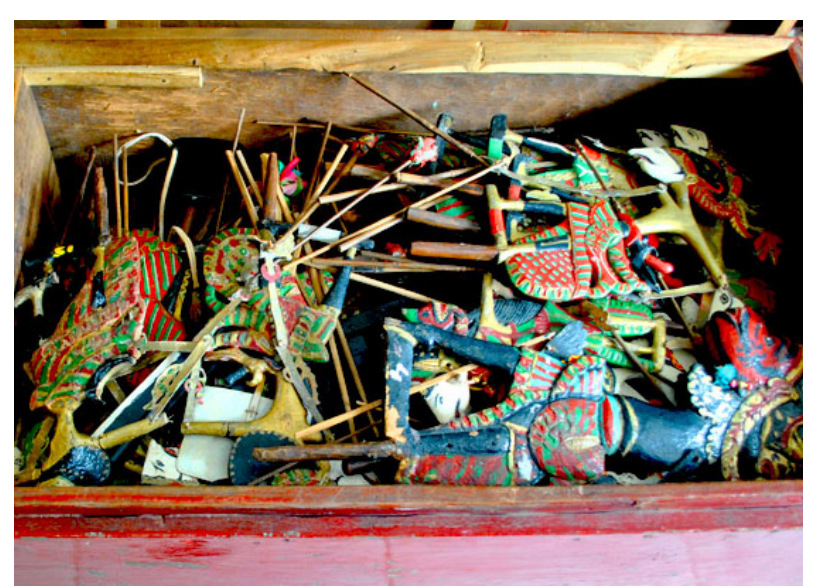

Figure 2. A set of Wayang Klithik which was said to be the only ones left.
"The relationship between past and present traditions must be closer. Tradition includes the continuity of the past in the present rather than merely showing the fact that the present comes from the past. The continuity of the past in the present has two forms, namely material or physical aspects, ideas or psychology, objective and subjective."

The new paradigm referred to in the article is the form and structure of Wayang Klithik which was studied and adapted from the form and structure of the traditional puppet show of the Kasunanan Surakarta Palace, while those considered to be old paradigms are forms and structures that were once abandoned the Wayang Klithik community of the Wonosoco Village.

Such is Pak Sumarlan, or commonly called Mbah Marlan who has consistently become the puppeteer behind Wayang Klithik in Wonosoco. Mbah Marlan became the puppeteer not because of heredity or inheritance. Mbah Marlan tells us that the process of becoming a puppeteer through it naturally, there is no special treatment or preparation. Mbah Marlan began masterminding in 1969 and after that routinely mastered the Sedekah Sendang ritual in Wonosoco Village. The traditional procession of resik-resik sendang is held by the residents of Wonosoco Village every year and held for two consecutive days, namely every July on Saturday Kliwon and Sunday Legi.

The description of the background of the problem raises problems that require answers and explanations. The formulation of the problem is as follows. (1) Why does the Wayang Klithik show use a new paradigm? (2) What is the new form of the paradigm of the Wayang Klithik Wonosoco Village show? (3) What is the structure of the new Wayang Klithik show paradigm? Such is Pak Sumarlan, or commonly called Mbah Marlan who has consistently become the puppeteer behind Wayang Klithik in Wonosoco. Mbah Marlan became the puppeteer not because of heredity or inheritance. Mbah Marlan tells us that the process of becoming a puppeteer through it naturally, there is no special treatment or preparation. Mbah 
Marlan began masterminding in 1969 and after that routinely mastered the Sedekah Sendang ritual in Wonosoco Village. The traditional procession of resik-resik sendang is held by the residents of Wonosoco Village every year and held for two consecutive days, namely every July on Saturday Kliwon and Sunday Legi.

The description of the background of the problem raises problems that require answers and explanations. The formulation of the problem is as follows. (1) Why does the Wayang Klithik show use a new paradigm? (2) What is the new form of the paradigm of the Wayang Klithik Wonosoco Village show? (3) What is the structure of the new Wayang Klithik show paradigm?

\section{Community Paradigm Changes}

At the beginning of the Millennium III, the development of society was so rapid as a result of globalization. Globalization encourages changes in the value system adopted by most of the world community, including Indonesia which has a variety of local cultures, including Javanese, especially the Wonosoco community in Kudus Regency.

Paradigm is a fundamental view of the subject matter of a branch of science, helping objects to be studied, problems that must be answered, and rules that must be followed in interpreting answers that must be obtained (Ritzer, 2004:86). Paradigms are also a collection of values that form a person's mindset as a point of view. The paradigm forms a person's subjective image of reality and its assumption in the form of a response to that reality. The paradigm is only suitable for a problem at a certain time. If the problem is different and the conditions are different, then the shift of the old paradigm towards a new paradigm that is considered more appropriate is a must. Changes in the value system foster a new paradigm in community art procedures.

Puppet show becomes a commodity that requires careful planning, high financing, requires evaluation of stage activities, and production quality control. Each puppeteer needs a group / group of supporting components that are relatively permanent to defend his artwork (Jazuli, 2003:253). A puppeteer is always tied to other supporting actors, even though he occupies a hierarchy and high status and a central role in the show, namely as the performance leader. Production staff have never dared to make their own decisions, in addition to following the will of the leader (puppeteer), even if it concerns his field of duty. In terms of the means of production, Suyanto grouped them into two categories, namely the physical furniture of puppet shows and supporting furniture. Physical furniture of the puppet show as follows. (1) gamelan instruments that are used as media or instruments that act as a source of sound / sound to play compositions, including songs, songs, and sulukan as supporters of the atmosphere of pakeliran. In the current development, the puppet gamelan instruments are enlarged and reproduced by the instruments, so that they become the instruments of the gamela ageng with the barrel slendro and pelog. The instrument of a large

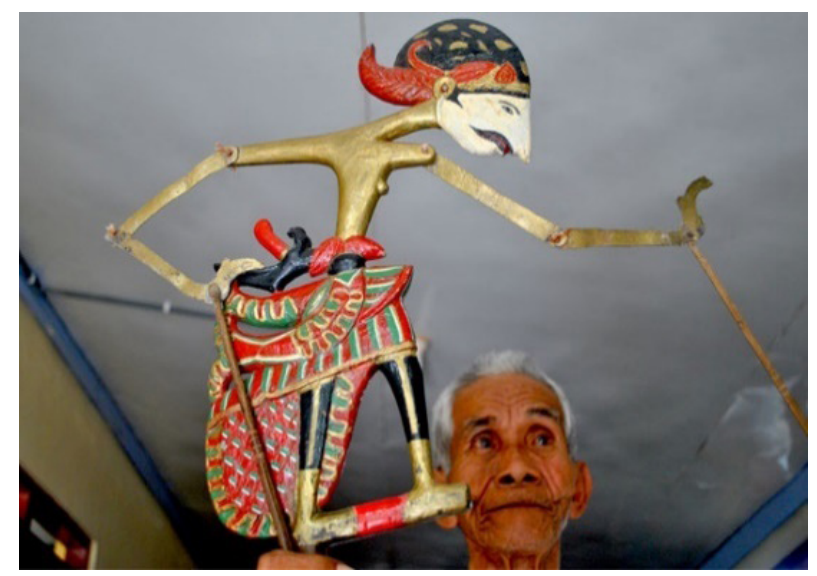

Figure 3. Mbah Marlan showed how to play Wayang Klithik with enthusiasm. (Photo: Aan Prihandaya) 
gamelan ageng is double which has caused its musicians (pengrawit) to be double. Even then it is still necessary to add non-gamelan instruments, such as bedug, orgen, and simbal. (2) Stage consisting of gawang, kelir, sligi, debog, tapak dara, placak, pluntur, and blencong/lampu. (3) The box is as a place to keep puppets that will be used and that have been performed. The box also functions as a source of sound with a bat in the form of cempala and a place to attach a series of keprak/kecrek, which are manipulated by the puppeteer. If the edge of the puppet box produces a sound dhodogan, so the keprak produces sound crek.. crek..crek. Wayang boxes are generally made of suren wood in a rectangular form complete with a lid. The box is placed to the left of the puppeteer, while the lid is placed on the right side of the puppeteer. Box is a series with keprak or kecrek and cempala. Keprak made of metal, such as bronze, brass, or monel with a standard size. One set keprak consists of four pieces of different thicknesses. Keprak hung on the outside on "lip" of the right front box (left of the puppeteer), right at the position of the right foot of the mastermind when the puppeteer sits cross-legged. Keprak arranged in such a way that it produces a sound that suits the puppeteer 's taste. The supporting physical furniture among them sound system, sound efect, and lighting efect (B. Murtiyoso qtd. in Suyanto, 2007:10).

In the Wayang Klithik show, instead of banana stems to plant puppets, wood materials are provided with holes permanently. This is seen as more practical and durable. The musical instrument is a set of gamelan gadon laras Slendro-Pelog. The gamelan does not use modern musical instruments, such as cymbals, orgen, and drum.

\section{Supporting Factors for Changing the New Paradigm of Wayang Klithik Wonosoco}

\section{Internal Factor}

Wayang Klithik Wonosoco show involving many citizens to take part and participate. At least 7 residents became pengrawit, one person as a puppeteer, another resident picked up the pesinden and prepared puppet show equipment, such as lifting a box containing puppets from the village office to the stage, which is located beside the spring. Some others prepare gamelan instruments, looking for fittings, such as mats, dishes, and other necessities. In the puppet show, the ones who get important treatment are the puppeteers and their paragas. They will feel happy carrying out the task if a conducive atmosphere is created. People also enjoy it, feel comforted and satisfied. People feel they have ownership of Wayang Klithik, so that the Wayang Klithik show is expected to be held every year. Although it is rare, the Wayang Klithik remains sustainable. Therefore, care and cooperation are needed for various parties to design, realize a strategic concept, implement conservation, and develop (Sikstono, 2013:337).

Puppeteer artists, pengrawit (musicians), and supporters of the show are

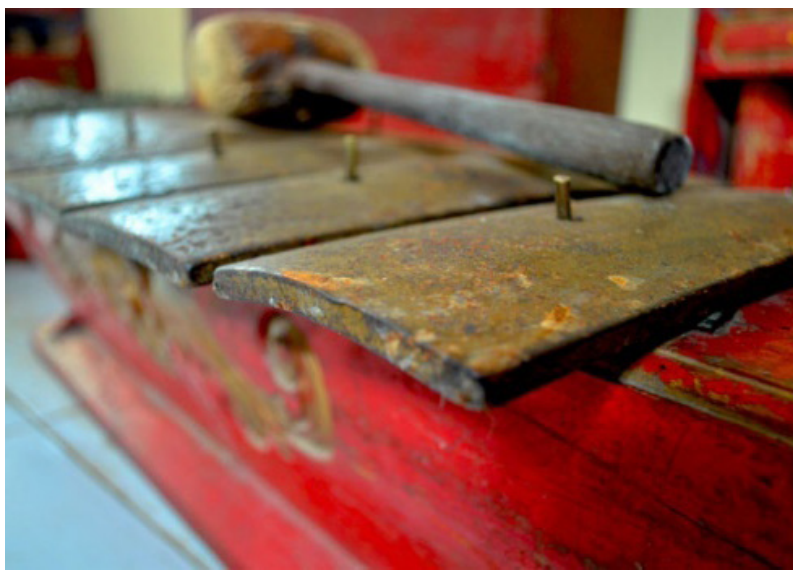

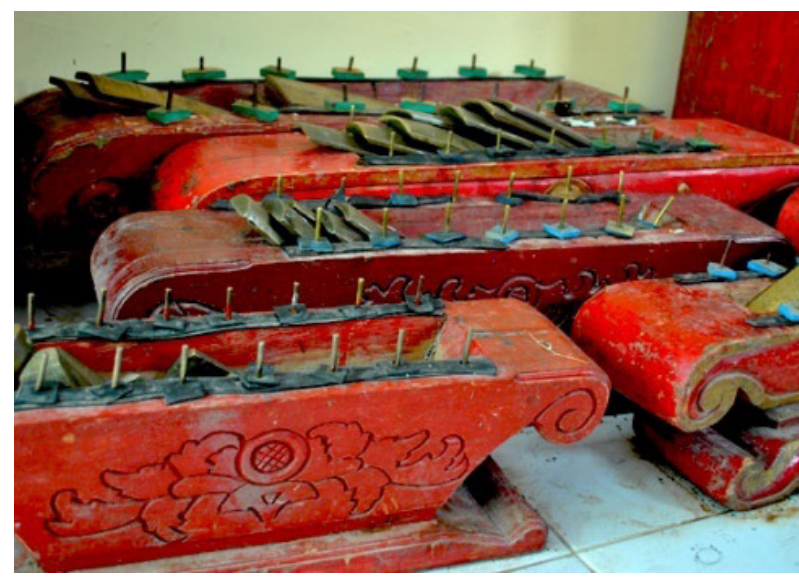

Figure 4. Demung, one of the gamelan instruments that accompanies the Wayang Klithik show. 
mostly domiciled in Wonosoco Village. Some of them were dissatisfied with the performances presented by the elder puppeteer, Ki Suparlan, caused by physical conditions which began to weaken because they were elderly and did not keep up with the times. The young puppeteer, Ki Sutikno, Sudarmin Village Chief, Chairman of the Ki Suprianto Art Group and Ki Slamet, studied the form and structure of Surakarta style puppetry in the Pasinaon Dalang Keraton Kasunanan Surakarta. They also served as servants of the Surakarta Palace, and for these efforts each received the title of cultural court official. It is a symbol to strengthen his identity in the presence of the Wonosoco Village community, so it influences the new paradigm of art.

Attendees who watched the Wayang Klithik in Wonosoco are not limited to local residents, both men and women, both old people and children. nThe audience from other villagers are intentionally present to participate in the sendang bersih desa ritual, and at the same time, they enjoy the performance of the Wayang Klithik. In the bersih desa ritual, all residents of Wonosoco Village pray for safety, prosperity, and common prosperity. Safety refers to the safety of all humanity in the village and in the city, the safety of land, water, all kinds of plants, animals and air. All of that underlies the existence of prosperity and welfare.

Wonosoco residents spend one day and one night to welcome the bersih desa ritual. In the morning, they prepare the procession which is then held in the afternoon which starts at around 3:00 p.m. until sunset. When the author made observations and a series of interviews, it was seen that almost all of the citizens of Wonosoco - young and old, teenagers, even children - returned at evening to the spring area (a lake that never dries and is the only clean spring for citizen). They stayed up late all night while watching various events in the play (calm, restless, conflict, difficult, happy, joyful, and others) to get a potrait of life guidance. The main character is considered to reflect the wisdom of his ancestors, so traditions can be carried out and adapted to the situation of the times. In such circumstances, they feel and expect to receive blessings and protection from ancestral spirits, local danyang, angels, and God Almighty. Other villagers who took part in enjoying the puppet show also greatly appreciated the form and structure of the show which was relatively new, even though it was in its original place, the Pasinaon Dalang Keraton Kasunanan Surakarta, including an old tradition. The palace tradition has been repeatedly used as a reference, cheered on, and developed, both by academics and artists from non-academics. The tradition is like a rock that is solidly deflecting every wave of waves, but still that tradition is used as a reference foundation for development. This reflects the victory of tradition, which also means that the tradition created by the Surakarta Kasunanan Palace is still recognized and is seen as relevant to the community's situation, although an adaptation or adjustment process needs to be done. In this context, the new and old paradigm depend on the point of view and assessment of the community. Communities from outside Wonosoco expressed their support for the presence of Wayang Klithik, so that it is always staged every year as local entertainment that is worth strengthening the sense of social solidarity of the people, giving spirit to the performing artists, and to the entire organizing committee for the preservation of Wonosoco Village customs.

\section{External Factor}

a. Tourism Department Influence

Some government officials and tourism agencies feel called to raise cultural heritage in the form of Wayang Klithik as one of the attractions in the series of Wonosoco Village natural attractions. In 2011, Wonosoco Village was used as a rural tour flanked by two hills which were greened with teak trees. They ensure beautiful scenery from the hills. On the left hill (if we come from the direction of the village), there are two 
caves that can be visited by the traveler. However, the road to these caves in 2012 has not been paved, so that during the rainy season, it is less comfortable for visitors.

The tourism agency also changes the concepts and forms of show and various supporting equipment. For example, the screen, which was originally from the klowong, it became white screen like the color of a shadow puppet show. Wayang Gunungan is also made like a gunungan (mountain) on wayang kulit made from buffalo leather, and after going through the tanning process, it is encrusted and colored with a certain pattern. Wayang Klithik was invited several times at the district level to perform in front of the Kudus DPRD building, in Alon-alon Kudus; it even once represented Kudus Regency to perform at Taman Mini Indonesia Indah Jakarta. The Tourism Office helped in improving the stage system. It also helps with the budget for road infrastructure improvements to facilitate access for tourists to Wonosoco Village.

They also built art buildings and other supporting facilities for tourist destinations. The show paradigm experiences expansion, which is originally only for rituals to be entertainment and spectacle (Jazuli, 2011:39). The form and type of entertainment art generally tends to pay less attention to the weight of its art, and the message to be conveyed is less actual, even tends to be instant which means easily available, fast, cheap, fast, and cashable, that is important in the past short time. Art quality tends to be secondary. It is indeed a common feature of entertainment tourism industry which often uses improper quality of art products.

b. Influence of Globalization

In Wonosoco village, most residents have television that can capture live broadcasts from various local and national stations, both in the form of news and various types of entertainment. It broadens the public's view of an art activity. In addition, it can foster constructive criticism of various arts activities in the community. That is also why the orientation of Wayang Klithik's show undergoes a change towards a new paradigm. There is a tendency for change in the meaning of the enrichment process of the functions of the Wayang Klithik show. Initially it was only a sacred dimension to fulfill the bersih desa ritual, then it was extended to profane side. The sacredness of the Wayang Klithik show is marked by the delivery of gratitude from all components of the Wonosoco Village community in a bersih desa ritual by offering prayers and praise to Gusti Kang Maha Agung, the Almighty God. All kinds of sacred art are postmodern, that is, transcending the boundaries of humanity with the aim of the pure end of human prostration to the Supreme One. Now the sacred aspects tend to be narrowed in scope, defeated by profane values that serve entirely for the benefit of modern humans who are trapped in material needs. At the same time, the economic aspects and modern technology are the main considerations that are used for everyday life and help represent the performing arts, such as electricity and sound systems.

The Wonosoco community since the last three years (before 2012) has changed rapidly from an agrarian society to a pre-industrial society. Improving the quality of society in the field of education and information technology has become a driving force in almost all sectors of life, which has an effect on the concept and implementation of art. Supporters of the Wayang Klithik show, especially from puppeteers and musicians (pengrawit), agreed to combine several other puppet art sources into Wayang Klithik by adding vocabulary to the forms and structures of the Yogyakarta 
and Surakarta styles. The combination of the two styles is expected to create a new model for Wonosoco Wayang Klithik shows. The merger process requires the power of puppeteer and pengrawit (musician) imagery that is implemented in creative work to be in harmony with the logic, ethics, and aesthetics of the Kudus Regency community, especially Wonosoco.

\section{Form of Wayang Klithik Show}

Changes in Wayang Klithik show can affect changes in community orientation. In contrary, changes in a society also affect the Wayang Klithik show, both in concept, form; and tools and means of performance. The understanding forms in abstract art is structure. In wayang, what is meant by structure is a set of interrelated relationships between components which form a unified whole. Structure refers to the arrangement of relationships between parts of a whole. In its concrete form, the form is in the form of an arrangement. The concept of form concerns parts of wholeness. In the context of Wayang Klithik show, the study of the form of show is a study of parts of the Wayang Klithik show as an art form. As a form of art, Wayang Klithik show are one of the aesthetics of human beings that always need beauty. The art form must always be attractive so that the audience can enjoy it. In the show requires audience's appreciation. Therefore, puppet shows as a series of plays consisting of sabet (motion), catur (verbal language and satra), sound (regular sounds produced by the presenter, both instrumental and vocal sounds), and likeness (various forms of character of puppet figures used to realize events) in front of an audience.

\section{Scene Structure of Wayang Klithik Show}

Jejer I: Keraton Purwacarita.

Accompaniment: gending Galak Ganjur Metaraman.

Character: Sri Mahapunggung, Sidik Wacana, Winarongko, Yudanegara.
Main story: The state is wiyodi/kepapak pedut experiencing pagebluk.

Sulukan: Pathet nem jugag. Anjrah ingkang puspito rum ....

Sidik Wacana was commenting on pagebluk which occurred because many residents had deviated from the rules. Therefore, a king along with a person must evaluate himself, draw closer to God.

Sulukan: Bumi Gonjang ganjing Sl.Nem

Babak Unjal: The Arrival of Raja Atas Angin, Prabu Yudalengkoro

Accompaniment: Galak Ganjur.

Sulukan: Kagok Metaraman

Main story: Prabu Yudalengkoro wants to propose Dewi Sri. He did not receive an answer yet, the envoy from Parang Garuda came, Patih Kala Dahono.

Sulukan: Pathet sanga jugag. Lelenging driyo mangu...kanin.ooo

The aim: Kala Dahono also propose Dewi Sri Ada-ada; Jajar muntap, lir Kinetap...ooo.

There was a cross of opinions from two messengers, so that a conflict occurred that had to be resolved through a power struggle. Budalan

Scene of Paseban Jaba'

Accompaniment: Galak Ganjur

Characters: Kala Dahono, Prabu Kala Maruto. Main story: Kala Dahono reported to Kala Maruto that there was an obstacle from Yudalengkoro who also wanted Dewi Sri so that a fight was needed.

Patih Yudapati fights Patih Kala Dahono. Prabu Juda Lengkoro fights Kala Maruto.

Before anyone wins or loses, comes the envoy from Purwacarito, namely Patih Winarongko.

Sulukan: Pathet sanga jugag, Lenglenging drio mangu....kanin.

Main story: Dewi Sri has disappeared, a contest appears, whoever can bring her home will be betrothed to Dewi Sri. All the messengers returned home looking for Dewi Sri.

Scene of Taman Purwacarita

Accompaniment: Galak Ganjur. 
Characters: Sidik Wacana, Dewi Sri.

Sulukan: Tinon lir kekonang...........ooo.

Main story: Dewi Sri became a struggle for several kings across the country, so she needed to be saved.

Dewi Sri was invited by Sidik Wacana to go to Arga belah.

\section{Scene of Goro-goro}

Sulukan: Lagon Slendro pathet sanga wetah Sangsaya dalu araras....Yogyakarta Style (Cipto Wardoyo, 1976:23). Greeted with song ilir- ilir Sl.sanga.

Accompaniment: Playon garap Metaraman, was connected to Sampak Yogya connected to lelagon Selendang biru.

Characters: Sabdo Palon, Nayagenggong, golek Tayub laki-laki, and Tejakusumo.

Lelagon Jineman uler Kambang, Bawa Caping Gunung jenggleng, gending Sambel Kemangi-Gelang kalung ditayubi oleh golek tayub pria, bawa Kutut Manggung Sl.dawah bokya Mesem, Sinom Nyamat Plg., bawa Sri Huning Sl. dawah goyang Semarang ditayubi golek tayub pria, Ada-ada kukusing dupa kumelum dawah gending Wolu sepuluh ditayubi golek tayub pria, gending Sidomukti metoke/munggah momong ditayubi, bawa Dandanggula rukum islam metoke gending ladrang Sholawatan Salamullah Shalatulah Sl. Disambung gending Galak ganjur mengiringi datangnya Tejokusumo.

Sulukan: Pathet sanga jugag, Lenglenging drio mangu....kanin....ooo

Main story: Tejakusumo's heart was sad because Dewi Sri left him. Tejokusumo invited panakawan to look for Dewi Sri.

Scene of Pertapaan Argo belah

Accompaniment: Galak Ganjur

Sulukan: Bumi Gonjang ganjing langit kelap kelap....ooo

Characters: Sidik Wacana, Dewi Sri.

Main story: Dewi Sri wants to return to Purwacarito. Dewi Sri's face was changed by Sidik Wacana to become a man, her name also changed to Bambang Sri Sardono. Dewi Sri in order to forcefully request the Purwacarito Palace from Sri Mahapunggung
Scene of Alas Rowo

Accompaniment: Galak Ganjur.

Sulukan: Pathet sanga jugag. Lenglenging drio mangu...kanin. ooo

Characters: Dewi Rukmo, Wijikoro.

Main story: Wijikoro felt hurt because his parents were favoritism, Mahapungung was made king, but Wijikoro was only given Alas gung which full of swamps. Wijingkoro will damage the land, welu pametu Purwacarito Accompaniment: Sampak Sala. Connected to Galak Ganjur.

\section{Scene of Perang Tejokusumo Melawan}

Wijikoro

Accompaniment: Galak Ganjur

Sulukan: Miat langening byar padang...oo

Characters: Tejakusumo, Wijingkoro Sabdo Palon, Nayagenggong

Sulukan: Galong wetah, Slendro pathet manyura (1976:31).

Meh raino............ooo

Main story: Wijikoro contradicted Tejokusumo's opinion. There was a match war.

Accompaniment: Sampak Sala.

Tejokusumo lost and he was running away to meet Sidik Wacana.

Main story: Sidik Wacana helped fight Wijikoro. Wijikoro was said to be a wild boar. Wild boar fled to meet Dewi Rukmo. Sidik Wacana said to wild boar and Dewi Rukmo. Wild boar was already Kinodrat; it cannot be a human anymore, wild boar went to the forest and asked for offerings saben seratus sampai seribu hari so that the offerings are given Gedang setangkep, .... kedua Jambe suruh .... ketiga timang trasi, .... keempat benang lawu .... if not served, farmers cannot reap agricultural produce.

\section{Scene of Purwacarita}

Accompaniment: Sampak Manyura.

Characters: Sri Mahapunggung, Sidikwacara, Tejokokusuma.

Main story: Talking about a battle between two kings of suitors who have not stopped.

Sidik Wacana transformed two animals, namely dogs and horses into two women resembling Dewi Sri, which was later named 
Dewi Sri Sonowati and Dewi Sri Kudawati. Two women were asked to seduce two war giants.

Scene in Medan Laga.

Accompaniment: Sampak Sala Manyura.

Characters: Yuda Lengkoro, Kala Maruta, Dewi Sri Sonowati, and Dew Sri Kudowati.

Yuda Lengkoro from Atas angin met Dewi Sri Sonowati, and he was willing to marry her. Kala Maruto from Parang Garuda met Dewi Sri Kudowati and he was willing to marry her.

\section{Scene of Purwacarita.}

Accompaniment: Sampak Sala manyura.

Characters: Sri Mahapunggung, Sidik Wacana, Yudo Lengkoro, Kolo Maruto, Bambang Sri Sardono

Main story: Yuda Lengkoro was married to Dewi Sri Sonawati, and he was asked to return to his country and take care of Purwacito's safety.

Kala Maruto was married to Dewi Sri Kudawati, and he was asked to return to his country and join in guarding the peace of Purwacarita.

Arrival of Bambang Sri Sardono.

Main story: Purwacarita will be conquered, Tejokusumo was angry, there is a war.

Scene of Perang Akhir

Accompaniment: Sampak Sala Manyura Characters: Bambang Sri Sardono, Tejokusumo.

Bambang Sri Sardono fights Tejokusumo. Bambang Sri Sardono badar became Dewi Sri.

\section{Scene of Tancep Kayon}

Accompaniment: Sampak Sala manyura.

Characters: Sri Mahapunggung, Sidik Wacana, Tejokusumo, Dewi Sri.

Main story: Pagebluk has passed, the state survived. The society look for the main story.As a warning, a party was held with a female Golek dance with accompaniment from Pangkur Lombo's music as a sign of the completion of the show.

\section{Analysis of Changes in the Form and Structure of Show}

The form and structure of the Wayang Klithik Wonosoco show which was exhibited by young puppeteer underwent a paradigm shift. The concept of the form of show is much influenced by tourism activities, as a result of globalization. The form of the show emphasizes more fun entertainment, more interesting than before. For example, a commotion scene which shows characters of Sabdopalon and Noyo Genggong that takes almost two hours or one third of the duration of the show. Beside to establish communication with the audience, a commotion uses the Yogyakarta style model. Work on the accompaniment starting with Sulukan; Lagon Slendro pathet sanga wetah, starting with Rhythm sangsaya dalu araras...... Yogyakarta style. Greeted song ilir-ilir Sl.sanga. Work on the next accompaniment; Playon garap Metaraman, connected with Sampak Yogya go through lelagon Selendang Biru.

The next opportunity is filled with requests from the audience. Complete Gending Lelagon Jineman Uler Kambang, Bawa Caping Gunung jenggleng, gending Sambel KemangiGelang kalung ditayubi by golek tayub pria, bawa Kutut Manggung Sl. dawah bokya Mesem, Sinom Nyamat Plg., bawa Sri Huning Sl. dawah goyang Semarang ditayubi golek tayub pria, Ada-ada kukusing dupa kumelum dawah gending Wolu sepuluh ditayubi golek tayub pria, gending Sidomukti metoke/munggah momong ditayubi, bawa Dandanggula rukum islam metoke gending ladrang Sholawatan Salamullah Shalatulah Sl. Disambung gending Galak Ganjur mengiringi datangnya Tejokusumo. Sulukan on pathet nem is dominated by Surakarta style garap sulukan. It is influenced by the process of puppeteer's learning that combines show of purwa shadow puppet of Yogyakarta style and Surakarta. Alur Plot lakon follows the Surakarta style consisting of Jejer, babak unjal, kedatonan, paseban Jaba, perang gagal, gara-gara, pertapan, Sabrangan, perang buruh, and tancep kayon. In its process, there is a division of accompaniment pathet, namely pathet nem, sanga, and manyura. Scene 
of pathet nem is started with jejer to perang gagal. Scene of pathet sanga in a commotion and pathet manyura after the battle scene. Process of accompaniment on pathet nem, musical accompaniment still uses one old pattern of gending, namely galakganjur Metaraman style, keprak uses Surakarta style. Garap sulukan more varied and there is one sulukan which is repeated, namely Lengleng ing Driyo mangu mangungkung .....................oooo cengkok Yogyakarta. Scene on pathet manyura, all work on accompaniment using the Surakarta style pattern, namely Srepeg and Sampak Sala, whereas sulukan takes the Yogyakarta style, namely Suluk Galong Wetah Slendro Pathet Manyura which starts with Meh raina......... until it's finished. After sulukan meh raina.......... there is no more sulukan. The concept of the form of show changes, that is, the old show always has a character that ends in death, while the new concept all ends with pleasure and success. In working on the concept is also influenced by the badar concept or the transition from the original form of the figure in the Yogyakarta-style shadow puppet show. Overall, the process of the play runs linear, interesting to be watched, and is entertaining. The ritual or sacred portion of the process is very thin and tends to be profane. In the scene of garagara, it is showed man Tayub Golek dance as new identity of Wonosoco Village which every year organizes tayuban in the framework of ritual ceremonies field nyiwer. At the end of the performance, the female golek dance was performed with the accompaniment of Pangkur gending, as a sign the performance is complete and the community is expected to be able to find the angsar or wisdom from the finished performance.

\section{Conclusion}

Wayang Klithik Wonosoco show experienced a new paradigm. The concept of the show is influenced by the Yogyakarta and Surakarta style shadow puppet shows. The old concept contained the main character who died, while the new concept, all the characters got happiness without failure. In the play also adopts the concept of badar, that is the character returns to his original formThe form of the show is influenced by the globalization of the world, the weight of artistic value is reduced, and the orientation to entertainment is pleasing to the community. Wayang Klithik show which was originally sacred for ritual purposes, tended to be profane with more entertainment. Some performances have shifted using purwa shadow puppet shows, such as kayon, kelir, and perangkat gamelan. Sulukan which is used also uses sulukan that is commonly used in purwa shadow puppet shows. The sound of music that was originally galak ganjur Metaraman is increased with Playon, sanga-sanga Yogya, Srepegan, and Sampak Sala.

\section{References}

Ciptowardoyo. (1976). Sulukan Pedalangan Ngayogyakarta. Surakarta: ASKI.

Kutha Ratna, Nyoman. (2010). Metodologi Penelitian Kajian Budaya dan Ilmu Sosial Humaniora pada Umumnya. Yogyakarta: Pustaka Pelajar.

Jazuli, M. (2003). Dalang Negara dan Masyarakat Sosiologi Pedalangan. Semarang: LIMPAD.

Jazuli, M. (2011). Sosiologi Seni Pengantar dan Model Studi Seni. Surakarta: Sebelas Maret University.

Murtiyoso, B. Sumanto, Suyanto. Kuwato. (2007). Teori Pedalangan Bunga Rampai Elemen Elemen Dasar Pakeliran. Surakarta: ISI .

Randyo, M. (2011). "Makna Simbolis Lakon Kangsa Adu Jago Dalam Pertunjukan Wayang Kulit Purwa" dalam Harmonia Jurnal Pengetahuan dan Pemikiran Seni, 11(1), 17-26.

Soetarno. (2005). Pertunjukan Wayang dan Makna Simbolisme. Surakarta: STSI Press. Solichin, Waluyo, Sumari. (2007). Mengenal Tokoh Wayang. Surakarta: Asih Jaya.

Solichin. (2010). Wayang, Masterpiece Seni Budaya Dunia. Jakarta: Sinergi Persadatama Fondation.

Subandi, (2010). Wayang Klithik Desa 
Wonosoco Undaan Kudus (Laporan Penelitian Mandiri). Surakarta: ISI.

Suparno, Slamet. (2009). Pakeliran Wayang

Purwa, Dari Ritus Sampai Pasar. Surakarta:
ISI Press Solo.

Suparno, Slamet. (2007). Seni Pedalangan Gagrak Surakarta. Surakarta: ISI Press. Solo. 